\title{
Sandhill Crane Nesting Record for Southern Saskatchewan
}

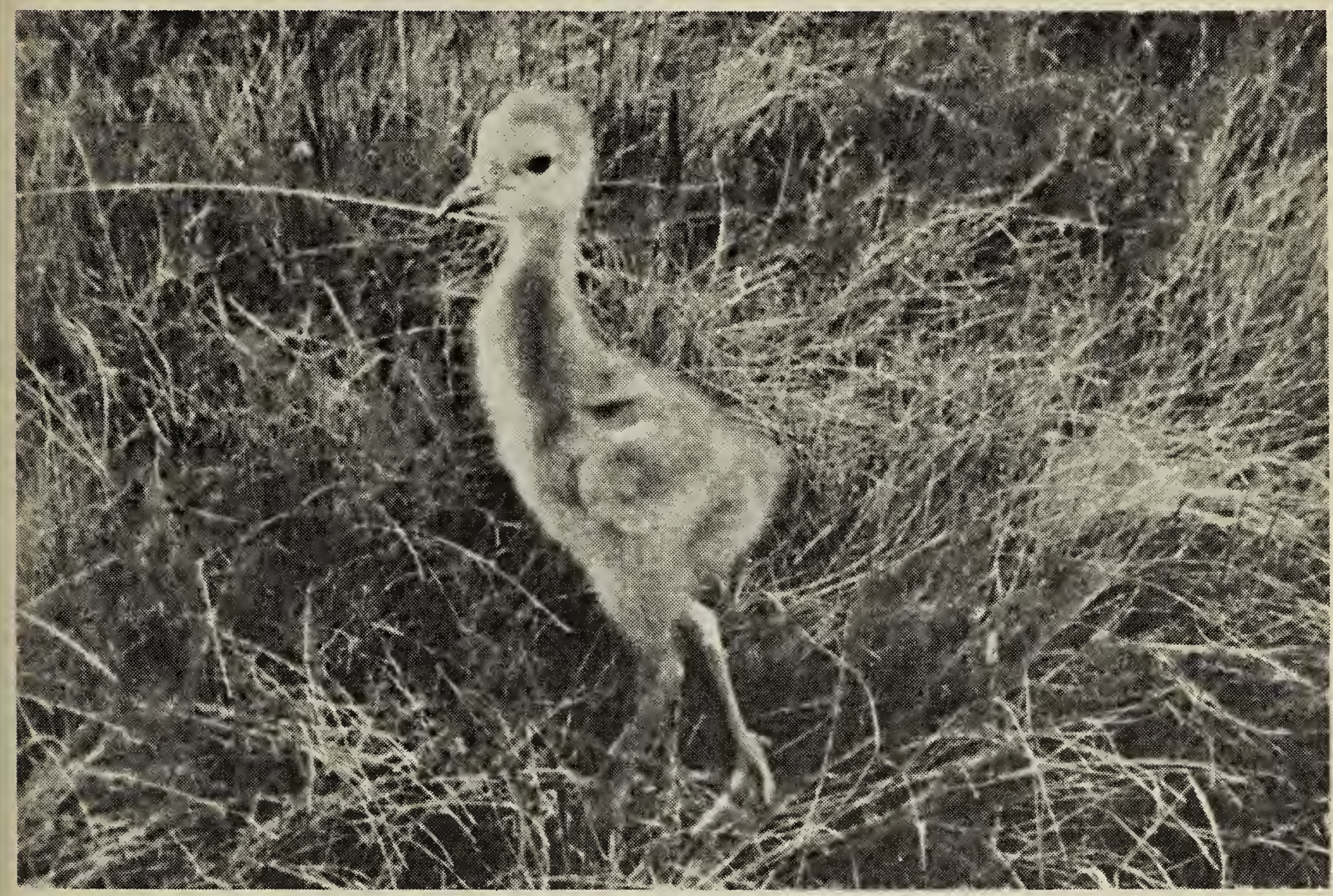

Photo by Mr. J. W. Inglis.

Downy young Sandhill Crane, June 14, 1964.

Mr. J. W. Inglis of Traynor, Saskatchewan, recently submitted to us two color slides of a downy young Sandhill Crane. These are of particular interest inasmuch as they were taken by Mr. Inglis "on June 14, 1964 , in the community pasture about 10 miles north of Traynor." Traynor is about 75 miles west of Saskatoon. On one of the slides, reproduced above, one can see that the young crane still bears the egg tooth, an indication that the bird was less than a week or two old. In this connection, note that June 2 is listed as the average of four hatching dates for this species in Canada (Walkinshaw, L. H. 1959. The Sandhill Cranes. Cranbrook Inst. of Sci., Bull. \#29, Bloomfield Hills, Michigan.). The scarcity of crane breeding records in Saskatchewan in recent years, especially in the south, was pointed out in an article in the Blue Jay in 1960 , to which interested readers are referred (Walkinshaw, L. H. 1960. Summer records of the Sandhill Crane in Saskatchewan. Blue Jay, 18:20-23). Mr. Inglis deserves thanks for having brought to our attention this interesting observation of the nesting of a species which has largely disappeared as a resident in this part of its range. Although his success as a photographer is evident from the black and white reproduction shown here, we regret that we are unable to show the original color slide.-The Editors.

\section{LAZULI BUNTING IN MOOSE JAW}

by Rosalind Taylor, Moose Jaw

Early in the morning of July 9 I saw a flash of vivid blue winging across our garden, but the glimpse was too fleeting to identify it. Later the same morning I stepped out onto the porch, binoculars in hand, to look at a bird I saw on the telephone wire, but I didn't look at that bird, for my eyes caught sight of that same lovely turquoise blue and there, perched on top of the telephone pole only a few yards away, was a beautiful male Lazuli Bunting. 